Came, H., \& Tudor, K. (2016). Bicultural praxis: the relevance of Te Tiriti o Waitangi to health promotion internationally. International Journal of Health Promotion and Education, 1-9.

doi:10.1080/14635240.2016.1156009

\title{
Bicultural Praxis: The Relevance of Te Tiriti o Waitangi to Health Promotion Internationally
}

Dr Heather Came and Dr Keith Tudor

School of Public Health and Psychosocial Studies, Auckland University of Technology,

90 Akoranga Drive, Northcote, Auckland 0627, New Zealand

Phone 064099219999

Corresponding author: heather.came@aut.ac.nz

Keith.tudor@aut.ac.nz

Acknowledgments: Thanks to Susan Da Silva, Maria Humphries, and Wiremu Woodard for feedback on drafts of this paper. 


\begin{abstract}
The transformation of health inequities between indigneous and non-indigneous people is necessary to any just society. Health promotion that addresses these injustices thus must be inherently political work particularly in colonial contexts with systemic inequities. Aotearoa New Zealand is one such context. We take as our starting point a commitment to implement bicultural praxis informed by interpretations of the articles of Te Tiriti o Waitangi (1840). This treaty sets in place governance arrangements between the indigenous people (Māori) and the Crown of Great Britain. This paper explores the application of this praxis within health promotion from a settler standpoint. Firstly it revisits the timeline leading to the signing of Te Tiriti, reviews the significance of Te Tiriti to health promotion practice in Aotearoa New Zealand, and proposes four imperatives to inform a bicultural praxis which, the authors argue, has an application internationally where indigenous and settler values must come into just relationship.
\end{abstract}

Key words: Indigenous people; social justice; biculturalism; Te Tiriti o Waitangi; Aotearoa New Zealand

\title{
Health Promotion is Political
}

Settler government policies and practices, such as colonisation and assimilation, have been linked to intergenerational conditions that threaten indigenous health (Gracey and King 2009, King, Smith, and Gracey 2009). As with the case for other first nations people, many American, Canadian, and Australian indigenous peoples were displaced from their traditional homelands and relocated to reserves lacking the services available to their non-indigenous counterparts (Kubik, Bourassa, and Hampton 2009). In Aotearoa New Zealand ${ }^{1}$ Lange (1999) argued legislation to end the traditional practice of rongoā (Māori medicine) and policy marginalised the use of Te Reo Māori (Māori language) has underminined holistic Māori health. Ineffective government action or, indeed, inaction in the face of the resulting high indigenous health needs has served to compound inequitable health outcomes over time.

These local experiences of a global colonial legacy and the political potential of health pomotion to mediate this legacy is rarely discussed in professional circles. Yet, health promotion praxis is grounded in ethical imperatives to reduce health inequities and social injustices, uphold human rights, and challenge discrimination (Health Promotion Forum 2011). Signal $(1998,257)$ maintained health promotion practice is inherently political and "the very nature of the enterprise requires shifts in power". This was reinforced in the emphasis on advocacy and healthy public policy in the Ottawa Charter (World Health Organization 1986, November). Reid (2002) argued that silence or neutrality about Māori and indigenous health and social justice issues constitues acceptance of the inequitable status quo. These ethical drivers make health promotion a unique platform from which to advocate for indigenous health and the reduction of inequities.

Strategic investment in addressing the wider determinants of health is another pathway to address health inequities (World Health Organization 2013). According to Mowbray (2007), indigenous determinants of health include navigating issues around access to land, decolonisation, racism, economic distribution, and self-determination. These areas are beyond the current scope of health investment in Aotearoa New Zealand (and, no doubt, other countries) which is focused on discrete bio-medical health targets (Ministry of Health 2013), and the essential functions of public health (New Zealand Public Health Clinical Network 2011).

\footnotetext{
${ }^{1}$ Our bilingual reference to the same geographical landmass reflects our commitment to bicultural praxis.
} 
Anti-racism activist, Nairn (2002) argued the role of settlers, as descendants of the colonisers, is different from that of indigenous people, the descendants of the colonised. The challenge for settlers she maintained is to continue to listen to indigneous people and to use our political competencies to advance indigneous aspirations. The role of settlers might be to challenge racism, a systemic barrier to indigenous success, and to promote accountability to indigenous people through inclusive governance and decision makaing structures. In New Zealand, for instance Māori remain under-represented in senior management across the public sector (State Services Commission 2010), and Māori providers are the least likely type of public health providers to be represented on government advisory committees (Came 2013). Thus, being allies standing in solidarity supporting indigenous-led solutions to health inequities and wider sovereignty campaigns becomes all the more critical.

\section{Aotearoa New Zealand Context}

It has been 175 years since the signing of Te Tiriti o Waitangi (Te Tiriti) between Māori (indigenous) hapū (sub-tribes) and the British Crown in Aotearoa New Zealand. Te Tiriti o Waitangi established the social contract between Māori and non-Māori and, as Henare (1987) maintained, from an indigenous standpoint, the passing of time will not change the fundamentals of this sacred covenant. Moreover, Te Tiriti will continue to be recognised in international law as a binding treaty between two sovereign peoples. For many Pākehā (New Zealand born settlers) and Tauiwi (overseas born immigrants), this document lays out the terms and conditions of our settlement in this land and, thus, it is referred to as the founding document of the (modern) nation. For many Māori Te Tiriti reaffirms tino rangatiratanga (sovereignty), which was previously proclaimed in 1835 in He Wakaputanga o te Rangatiratanga Nū Türei (Declaration of Independence) (Durie et al. 1989).

Debate about the interpretation and meaning of Te Tiriti has been prominent among Pākehā and Tauiwi since the 1970s and 1980s. It was fuelled firstly by the deliberate and active promotion by successive New Zealand governments of the English language version of Te Tiriti, contrary to the principle of contra preferentum, whereby the indigenous language version of a treaty takes preference over that written in the languages of the colonisers (Te Puni Kōkiri 2002, 19); and, secondly, by sets of Treaty "principles" authored by various Crown agencies (Hayward 1997). This paper assumes the pre-eminence of the Māori language text of Te Tiriti and recognises the Independent Commission of Inquiry - Waitangi Tribunal's (2014) WAI 1040 report that affirms that the Ngāpuhi tribes - and, by implication, other hapū - never ceded sovereignty.

Durie (1994) argues prior to colonisation Māori were in robust physical and mental health. Māori organised communally in such a way that everyone had responsibilities to fulfil for the collective and, in turn, were provided for. There was an abundance of food from cultivation, fishing, and hunting, which was traded amongst different hapū for scarcer goods. Māori had well-developed education, justice, and health systems guided by tikanga (rules/protocol) that were - and have continued to be - handed down through generations. There was a rich oral culture, and complex ceremonies of pōwhiri (welcome), poroporoaki (farewell), and tangihanga (death). Marriages were used to forge political alliances between hapū, and warfare was also used to settle disputes and acquire land and other resources. Māori had guardianship over all their lands. 
Durie (1994) argues prior to colonisation Māori were in robust physical and mental health. This wellbeing was maintained through a communally organised society with intricate systems of trade, education, justice and political alliances. By the early 1800s the whalers, traders, convicts, and eventually the missionaries and settlers arrived. These waves of people brought new technology and new ideas sometimes actively taken up and adapted by Maori. However, they presence of the newcomers also spread infectious diseases. The introduction of muskets, money, alcohol and tobacco and significant impacts. Some of the interactions between settlers and Māori were positive; others had an enduring negative impact. In the early 1800s, Māori rangatira (chiefs) gathered regularly at Taiāmai to discuss areas of mutual interest and alliances through a body known as Te Wakaminenga which operated similarly to the United Nations does today (Healy, Huygens, and Murphy 2012). After thirty years of dialogue, it was this collective that wrote He Wakaputanga o Te Rangatiratanga o Nü Türei (Waitangi Tribunal 2014).

In 1840 Māori negotiated a treaty with the British Crown to advance areas of mutual interest (Orange 2011). At that time Māori still controlled much of their land, were experienced in warfare and had a significantly larger population than non-Māori (between 80100,000, compared with 20,000). The British were keen to advance their "colonial project" and to achieve the goals of the Empire in terms of access to land and resources. The Māori text of Te Tiriti has four articles. The first that of kāwanatanga or governorship, outlined the Crown's obligations and responsibilities to govern its own people. The second, that of tino rangatiratanga affirmed Māori sovereignty over Māori affairs and taonga (treasures) including health (Barrett \& Connolly-Stone, (1998). Article three, guarantees Māori the same rights and privileges as British subjects. The fourth article (an oral one) affirmed the right to religious freedom and customary law.

The historical evidence, as documented in Waitangi Tribunal reports, shows that Te Tiriti has been consistently breached by a series of settler governments. Even according to Western frameworks, Māori now experience significant health inequities compared with other New Zealanders (Ministry of Health 2014). Critically, there is an average life expectancy gap between Māori and non-Māori men of 8.2 years and for women of 8.7 years (Marriott and Sim 2014). Māori continue to have high rates of incarceration, low education attainment, and low income. Many Māori now live in conditions that put their health at risk.

Durie (1989) and others have well established the connections between Te Tiriti and hauora (health). Within the health sector, the New Zealand Public Health and Disability Act 2000 outlines the legal obligations of the sector to recognise and respect the principles of the Treaty of Waitangi. It also requires the sector to prioritise improving Māori health outcomes, enabling Māori to contribute to decision-making and to participate in the delivery of health services. This is reinforced in a plethora of policy documents and statements from Salmond's (1986) pioneering memo about the Treaty, through to the New Zealand Health Strategy (King 2000), to the updated He Korowai Oranga (Ministry of Health 2014).

The New Zealand health promotion community has engaged with Te Tiriti and this commitment since the 1990s is embedded with our health promotion ethical guidelines and competency documents (Health Promotion Forum 2011). Within these documents Te Tiriti is presented as a framework for Māori to exercise control over their health and is upheld as the foundationof health promotion practice. In the competency document, the Tiriti-specific ethical principle stated: "Respect for, and commitment to, and protection of Te Tiriti o 
Waitangi, including the application of Te Tiriti o Waitangi to the actions and everyday practice of health promotion” (Health Promotion Forum 2011, 9).

The consistent application of Te Tiriti o Waitangi in the health and other sectors is what we refer to as Tiriti-based or bicultural praxis. Popularised as a concept by Freire (2000/1970), praxis is a process by which theory is practised and/or embodied, and enacted or realised. It is an ongoing process of action and reflection that, in Freire's works, is based on a pedagogy or andragogy (adult education) - of the oppressed, a commitment to action/learning as a process which is in pursuit of emancipation. Similarly, Tiriti-based praxis is in pursuit of Te Tiriti being honoured and the achievement of equitable health outcomes for Māori.

\section{Imperatives from Te Tiriti Praxis}

Alice Walker (cited in Parmar 2011) talked about activism as being her rent for living on this earth. Given the colonial legacy of injustice, deprivation and disparities between indigenous and non-indigenous people, we the authors argue that embracing Tiriti-based praxis is our 'rent' for living on this land. We have each wrestled with the application of Te Tiriti for considerable time: the first author from the perspective of a seventh generation Pākehā New Zealander engaged in anti-racism activism over decades; the second author from the standpoint of anti-racist activism overseas and, since settling in Aotearoa New Zealand, being engaged in bicultural dialogue in his profession.

The following five imperatives have emerged from ongoing dialogue with activists, practitioners, and academic colleagues, and teaching Te Tiriti to students from diverse backgrounds. We hold that these imperatives are directly applicable to health promotion and its education. Although they are founded in our experience and analysis of practice in Aotearoa New Zealand, we suggest that may also be useful in supporting practitioners from other dominant settler cultures to strengthen their engagement with indigenous communities (see Campbell et al, 2014; Varghese, Gopal \& Thomas, 2011; Makhubele, 2011; Stewart, 2008).

\section{That practitioners learn the history of the land on which one practices}

Every pocket of land in this - and any other - country speaks and carries with it a story. Despite being a nation with a relatively short history, many New Zealanders complete their education system without learning Māori or colonial history. The collusion and involvement of Pākehā ancestors in the violent colonisation of Aotearoa New Zealand is conveniently forgotten. To work effectively in this country we believe that it is important to have a an understanding of what happened here. Whereas European worldviews are oriented to the future, it is said that Māori walk backward into the future (Hirsch and Stewart 2015). Within this world view what happened 175 years ago and more remains present and has contemporary relevance.

This need to understand history is particularly potent in the context of Taranaki where the first author worked for some years. In the 1870s and 1880s Taranaki was a thriving community led by the prophets Te Whiti o Rongomai and Tohu Kākahi. It was the site of peaceful resistance by Māori disposed of their lands (Scott 1981). In 1881 the village of Parihaka was looted and destroyed by government forces. Many men were wrongfully arrested without trial, women were raped, and the remaining inhabitants were expelled and dispersed. The Waitangi Tribunal (1996) has described this attack as genocide. Much of the land in this area was then leased by the government to Pākehā settlers on 99 year perpetual leases which remain in place to this day. 
This colonial legacy of land alienation, coupled with policies of assimilation, has undermined many Māori families and continues to reveal itself in the over-representation of Māori in negative health statistics (Robson and Harris 2007), e.g. in high suicide rates amongst Māori (Joseph 1996), and, more generally as intergenerational trauma (Smith \& Reynolds, (2013). To work in this land we must be suspicious of hegemonic discourses of Māori failure, as documented by Moewaka Barnes, Borell, Taiapa, Rankin, Nairn, \& McCreanor (2012), and look more deeply at the causes of inequity and how these might be transformed.

\section{That the practitioner observes and nurtures cultural good manners}

According to Bishop, Ladwig \& Berryman (2013), whanaungatanga is an active process of relationship-building that lies at the heart of Tiriti-based practice. Central to engagement in te ao Māori (the Māori world) is the process of unravelling the complex web of relationships - who you are meeting? what is their whakapapa (genealogy)? who are their people (iwi)? what is their story? what mutual relationships and/or connections do we have? who stands behind them and will speak for them? These questions relate to rituals of encounter, which, once initially completed, are reiterated and enhanced over time. As a result of this and the honouring of commitment, trust is established and relationships are built and deepened. Ideally relationships become reciprocal and are robust enough to allow authentic dialogue between parties in both fair and foul weather. This process when done well ensures that health promotion work remains on track and relevant to the needs and aspirations of Māori (see also imperative four).

For non-Māori entering into whanaungatanga process involves understanding ones' own cultural standpoint and developing a base of "cultural good manners" (G. Berghan, personal communication, 28 October 2000). Haggis and Schech (2000) argued that, when engaging in such processes, Pākehā feminists need to own their privilege and partiality and to listen deeply to indigenous people. From a dominant cultural standpoint, it is comfortable to remain within the powerful cultural default position, that one's worldview and status (white, male, middle-class, heterosexual, etc.) is normal, ordinary, and neutral. In order to work cross-culturally, monoculturalism and cultural neutrality need to be interogated (Naughton \& Tudor, 2006). This can be achieved experientially, through being willing to walk a mile in someone else's shoes and through consciously developing cultural competencies through attending courses, being mentored, and/or through trial and error.

In Aotearoa New Zealand national competency documents (Health Promotion Forum 2011) require practitioners to be proficient in Māori concepts, principles and practices of health, and to be able to embed these in planning, implementation and evaluation. At the micro level of interpersonal communication this involves being able to pronounce Māori words correctly, through to being able to follow tikanga (protocol) at and on the marae (a traditional meeting place). At the macro level they include a commitment to anti-racism praxis and advocating for the removal of impediments to Māori health aspirations, such as institutional racism.

\section{That the practitioner actively support the continuation and restoration of indigenous control and authority}

Māori are the indigenous people of Aotearoa New Zealand. To use a dancing metaphor, this means that Māori get to lead. For Pākeha and Tauiwi this also means not picking the music, the outfits, or when the dance starts or finishes. Ideally it means not stepping on 
one's partners' feet! Our role is to remove barriers on the way to the dance floor and to keep up with our Tiriti partner, contributing what we can.

To embrace Tiriti-based practice, Pākehā and Tauiwi need to work through discomfort, to cede control, and to share public health resources, however scarce. Rob Cooper, a leader in Māori health, often asks the question "If you are interested in justice, what are you prepared to give up to achieve that?” (Personal communication, 28th October 2009.) Similarly Ramsden $(1994,4)$ maintained: "it is not normal for any group in control to relinquish power and resources to the less powerful simply on the grounds of goodwill or a sense of moral obligation.” For many non-Māori, this is a leap of faith they are unwilling or ill-equipped to take. For those that do, the personal and interpersonal rewards in reaching this relational place of trust, and being acknowledged as a Tiriti partner are profound and life-altering.

When engaging in Tiriti-based practice, it is useful to set up systems and processes to be accountable to Māori. This can be negotiated through an informal relationship with a kaumātua (elder) or Māori colleague, or a more formal governance such as an advisory group which is willing to provide cultural and political direction. For instance, the antiracism movement in Aotearoa New Zealand has developed systems and processes whereby it is accountable to a collective in order to ensure that those doing anti-racism work are supported and are in reflective dialogue with peers (Network Waitangi Otautahi 2002).

Developing plans that are responsive to the articles of te Tiriti and monitored by Māori is another way to move forward, one careful step at a time. These plans usually involve a stocktake of where a program is in terms of its engagement with Māori, and then the identification of measurable steps to strengthen and extend existing efforts. Critical to Tiriti-based praxis is the ability to monitor and measure progress to which end a range of audit tools and frameworks have been developed to assess performance in this area including the Cultural Audit Tool (Durie 1993), He Tuara Tieke (Cunningham 1995), and the Whānau Ora Impact Assessment (Ministry of Health 2007). Such praxis meets the goals of Tiriti-based practice guidelines on participation as outlined in the document Treaty Understanding of Hauora in Aotearoa-New Zealand (HPF, 2000).

\section{That the practitioner prioritise work that advances indigenous aspirations}

In order to prioritise Māori aspirations one must first identify what they are. This process involves engagement with Māori and the mobilisation of professional networks. Māori aspirations are well documented in hapū planning documents, the proceedings of health hui (gatherings) and publically available submissions held by Crown agencies. Since there 1980s there has been strong continuity in terms of Māori aspirations up to and including the release of the Whānau Ora Taskforce's Report (2010).

In 1984 the Māori Women's Welfare League (MWL) conducted a landmark survey, the health needs of Māori women (Murchie 1984). This study recommended the introduction of holistic programmes that strengthened whānau wellbeing and inspired rangatahi (young people) to take pride in their health. An holistic approach to health is echoed in most if not all accounts of indigenous perspectives on health (e.g., Campbell et al, 2014; Stewart, 2008; Varghese, Gopal \& Thomas, 2014). During the subsequent Māori health decade (1984-1994) Māori called for investment in initiatives that fostered cultural identity, selfesteem, confidence, and pride (Ministry of Health 1998). Emphasis was on programmes 
that allowed Māori voices to be heard, and encouraged Māori to take control over their destiny. Māori sought economic security, whānau support, cooperative action, and programmes that balanced intellectual alertness, physical fitness, and spiritual awareness. Central to these and other aspirations has also been calls for the return of Māori land and the protection and promotion of te reo rangatira (the Māori language). To date, only small pockets of the health sector have found the flexibility, courage, and capacity to pursue these holistic aspirations.

\section{Conclusion}

Te Tiriti o Waitangi is a potent framework for health promotion practice in Aotearoa. It puts the aspirations of indigenous people at the heart of practice. It demands equitable outcomes and involvement in decision-making around the design, delivery and evaluation of health services. There is a need for urgent action to address the current inequities between Māori and non-Māori. Rather than focus on the symptoms of poverty and the distress that it causes, health promotion needs to focus on community action and developing healthy public policy that challenge the structural causes of poverty and inequities. The imperative the authors have identified offer a way of holding important principles and values that inform such action and policy.These imperatives may have relevance in other jurisdictions engaging in decolonisation. 


\section{References}

New Zealand Public Health and Disability Act 2000 (S.N.Z. No.91.).

Barrett, Mark, and Kim Connolly-Stone. 1998. The Treaty of Waitangi and social policy. Social Policy Journal of New Zealand (11), http://www.msd.govt.nz/about-msd-and-ourwork/publications-resources/journals-and-magazines/social-policy-journal/spj11/treaty-ofwaitangi-and-social-policy.html.

Bishop, R, J Ladwig, and Mere Berryman. 2013. "The centrality of relationships for pedagogy: The whanaungatanga thesis." American Educational Research Journal no. 51 (1):184-214. doi: $10.2102 / 0002831213510019$.

Came, H. 2013. "Beginning to address institutional racism within the public health sector: Insights from a provider survey." Keeping up to date no. 38 (Autumn/Winter):1-9.

Cunningham, Chris. 1995. "He taura tieke: Measuring effective health services for Maori." In. Wellington, New Zealand: Ministry of Health. http://www.nmdhb.govt.nz/filesGallery/New\%20Website/09Board\%20Documents/HeTauraT iekeMeasuringEffectiveHealthServicesMaori.pdf.

Durie, ETJ, PB Temm, WM Wilson, and S Kenderdine. 1989. The Treaty of Waitangi. In New Zealand Law Society Seminar. Wellington, New Zealand: New Zealand Law Society.

Durie, Mason. 1989. The Treaty of Waitangi and healthcare. New Zealand Medical Journal 102 (869): 283-5, http://journal.nzma.org.nz/journal/.

Durie, Mason. 1993. "The CHI model: A culturally appropriate auditing model: guidelines for public health services." In. Wellington, New Zealand: Public Health Commission. Ministry of Health website:

http://www.moh.govt.nz/notebook/nbbooks.nsf/0/C7D01BF660F8028A4C2565D700186921/ \$file/92509.pdf.

Durie, Mason. 1994. Whaiora: Māori health development. Auckland, New Zealand: Oxford University Press.

Freire, Paulo. 2000/1970. Pedagogy of the oppressed (M. Ramos, Trans.) (Original work published 1970). New York, NY: Continuum.

Gracey, Michael, and Malcolm King. 2009. "Indigenous health part one: determinants and disease patterns." The Lancet no. 374 (9683):65-75. doi: 10.1016/S0140-6736(09)60914-4

Haggis, Jane, and Susanne Schech. 2000. "Meaning Well and Global Good Manners: Reflections on White Western Feminist Cross-cultural Praxis." Australian Feminist Studies no. 15 (33):387399. doi: 10.1080/713611987.

Hayward, Janine. 1997. The principles of the Treaty of Waitangi. In Rangahau whanui national overview report, edited by Allan Ward. Wellington, New Zealand: Waitangi Tribunal.

Health Promotion Forum. 2011. "Ngā kaiakatanga hauora mō Aotearoa: Health promotion competencies for Aotearoa-New Zealand." In. Auckland, New Zealand: Author. http://www.hpforum.org.nz/assets/files/Resources/Final\%20Sep\%202011.pdf.

Healy, Susan, Ingrid Huygens, and Takiwai Murphy. 2012. Ngāpuhi speaks. Whangarei, New Zealand: Network Waitangi Whangarei, Te Kawariki.

Court of Appeal of New Zealand. 1987. Affidavit for New Zealand Maori Council v the Minister of Finance (CA. 54/187). May.

Hirsch, E, and C Stewart. 2015. "Introduction: ethnographies of historicity." History and Anthropology no. 16 (3):261-274.

Joseph, Paul. 1996. "Colonisation and Maori youth suicide." Youth Law Review no. 33:5-9.

King, Annette. 2000. "The New Zealand health strategy." In. Wellington, New Zealand: Ministry of Health. Ministry of Health website:http://www.health.govt.nz/publication/new-zealandhealth-strategy.

King, Malcolm, Alexandra Smith, and Michael. Gracey. 2009. "Indigenous health part two: The underlying causes of the health gap." The Lancet no. 374 (9683):76-85. doi: 10.1016/s01406736(09)60827-8.

Kubik, Wendee, Carrie Bourassa, and Mary Hampton. 2009. "Stolen sisters, second class citizens, poor health: The legacy of colonization in Canada " Humanity \& Society no. 33 (1/2):18-34.

Lange, Raeburn. 1999. May the people live: a history of Maori health development 1900-1920. Auckland, New Zealand: Auckland University Press. 
Marriott, Lisa, and Dalice Sim. 2014. Indicators of inequality for Māori and Pacific people [Working paper 09/2014]. Wellington, New Zealand: Victoria University.

Ministry of Health. 1998. Whaia te whanaungatanga: Oranga whanau: The wellbeing of whanau: the public health issues. Wellington, New Zealand: Author.

Ministry of Health. 2007. Whānau ora health impact assessment. Wellington, New Zealand: Author.

Ministry of Health. Health targets 2013 [cited 6 December 2013. Available from http://www.health.govt.nz/new-zealand-health-system/health-targets.

Ministry of Health. 2014. The guide to he korowai oranga: Māori health strategy. Wellington, New Zealand: Author.

Moewaka Barnes, A, B Borell, K Taiapa, Jenny Rankin, Raymond Nairn, and Tim McCreanor. 2012. "Anti-Maori themes in New Zealand journalism; toward alternative practice." Pacific Journalism Review no. 18 (1):195-216.

Mowbray, Martin. 2007. "Social determinants and indigenous health: The international experience and its policy implications: Report on specially prepared documents, presentations and discussion on the International Symposium on the Social Determinants of Indigenous Health." In. Adelaide, Australia: Commission on Social Determinants of Health. World Health Organization, Commission on Social Determinants of Health website: http://www.who.int/social_determinants/resources/indigenous_health_adelaide_report_07.pdf (accessed 29-30 April).

Murchie, Elizabeth. 1984. Rapuora: Health and Maori women. Wellington, New Zealand: Maori Women's Welfare League.

Nairn, Mitzi. 2002. "Decolonisation for Pakeha." In Pakeha treaty work: Unpublished material, edited by Jennifer Margaret, 203-208. Auckland, New Zealand: Manukau Institute of Technology, Treaty Resource Centre.

Network Waitangi Otautahi. 2002. "Protocols and ethics for Network Waitangi tiriti workers." In Pakeha treaty work: Unpublished material, edited by Jennifer Margaret, 214-15. Auckland, New Zealand: Manukau Institute of Technology, Treaty Resource Centre.

New Zealand Public Health Clinical Network. 2011. Core functions of public health. Wellington, New Zealand: Author.

Orange, Claudia. 2011. The Treaty of Waitangi. 2nd ed. Wellington, New Zealand: Bridget Williams Books.

Parmar, Pratibha. 2011. Alice Walker: Beauty in Truth. Kali Films Production

Ramsden, Irihapeti. 1994. A challenge to education. Social Policy Journal of New Zealand (3), http://www.msd.govt.nz/about-msd-and-our-work/publications-resources/journals-andmagazines/social-policy-journal/spj03/03-challenge-to-education.html.

Reid, Papaarangi. 2002. Challenging knowledge, challenging practice. In Making the Connections: Health Promotion Forum Conference. Christchurch, New Zealand: Health Promotion Forum.

Robson, Bridget, and Ricci Harris, eds. 2007. Hauora: Maori standards of health 4. A study of the years 2000-2005. Wellington, New Zealand: Te Ropu Rangahau Hauora a Eru Pomare

Salmond, George. 1986. Circular memorandum No.1986/70. Wellington, New Zealand: Department of Health.

Scott, Dick. 1981. Ask the mountain. Auckland, New Zealand: Reed.

Signal, Louise. 1998. "The politics of health promotion: Insights from political theory." Health Promotion International no. 13 (3):257-263. doi: 10.1093/heapro/13.3.257.

Smith, Cherryl, and Paul Reynolds. 2013. Researching Māori intergenerational trauma. In Tamiora Research Seminar. University of Auckland.

State Services Commission. 2010. "Equality and diversity report: Diversity in the senior management of the public service." In. Wellington, New Zealand: Author. http://www.ssc.govt.nz/sites/all/files/2010-e\&d-report.pdf.

Te Puni Kōkiri. 2002. "He tirohanga ō kawa ki te Tiriti o Waitangi." In. Wellington, New Zealand: Author. http://www.tpk.govt.nz/en/in-print/our-publications/publications/he-tirohanga-okawa-ki-te-tiriti-o-waitangi/download/tpk-treatyoverview-2001-en.pdf.

Waitangi Tribunal. 1996. "The Taranaki report: Kaupapa tuatahi [WAI 143]." In. Wellington, New Zealand: Author. http://www.waitangi- 
tribunal.govt.nz/scripts/reports/reports/143/55B2A0E3-DD7B-4E1B-A824-

9F046DECD328.pdf.

Waitangi Tribunal. 2014. Te paparahi o te raki [Wai 1040]. Wellington, New Zealand: Author.

Whānau Ora Taskforce. 2010. "Whānau ora: Report of the taskforce on whānau -centred initiatives."

In. Wellington, New Zealand: Minister for the Community and Voluntary Sector. Ministry of Social Development website: http://indigenous-mental-health.ca/index.php/onlinelibrary?sobi2Task=sobi2Details\&sobi2Id=201.

World Health Organization. 1986, November. Ottawa charter for health promotion. In Proceedings of the 1st international conference on health promotion Ottawa, Canada: World Health Organization.

World Health Organization. 2013. The economics of social determinants of health and health inequities: A resource book. Luxembourg: Author. 